\title{
結核ワクチン(丸山ワクチン)の生化学的 分析とその活性因子に関する研究
}

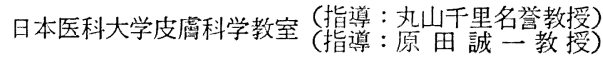 \\ 三 好 朋 子*
}

緒言

結核症は，種々の抗結核郕の普及により，、まやお それるにたりぬ疾患とされている感がある。しかしな がら, 化学療法にもその副作用, 耐性獲得など, 多く の解決すべき点が残されている。

われわれの教室においては，抗結核剂発見以前の 1944 年に, 丸山 ${ }^{12}$ がヒト型結核菌より分離抽出した 特異抗原性物質を, ワクチンとして皮膚結核の治療に 用いて以来, その研究が続けられ, 本療法の応用は, 皮虞結核のみならず，肺結核，癭にまで执よび，その 効果についてはすでに詳細に報告されている2。

本物質に関する基礎的研究は, 免疫血清学方面につ いて, 松下 ${ }^{3)}$, 新海 ${ }^{4)}$, 浦边 ${ }^{5)}$, 福本 ${ }^{6)}$, 文入 ${ }^{7)}$, 本田 ${ }^{81}$ などの，また皮膚反応については，飯田 ${ }^{9)}$ ，平井 ${ }^{10)} ら$ の報告がある。

本物質の成分に関しては，従来定性反応により，多 糖体を主とし，蛋白質，核酸を含む複合多糖体とい5 推測がなされていた。

今回著者は，本物質のさらに精しい生化学的分析を 行ない，また本物質による皮内反応を精製ツベルクリ ン(PPDs) のそれと比較検討した結果, その活性因 子を示唆すべき 2,3 の事実をらることができたので報 告する。

\section{1. 生化学的分析}

\section{(1) 実験材料}

丸山の結核ワクチンには， A, B , C , D の 4 種があ り, 臨床的に使用されるのは，主に A, C, D の 3 種 である。ここにその調製法をつぎにのべる。

1） ワクチン $\mathrm{A}$ の調製法（表 1 ）

菌体湿潤重量 $50 \mathrm{~g}$ より, $30.8 \mathrm{mg}$ の黄褐色の粉末 を得た。

2）ワクチンCの調製法（表 2)
菌体湿潤重量 $140 \mathrm{~g}$ より, $34.7 \mathrm{mg}$ の白色粉末を 得た。

3） ワクチンDの調製法（表 3)

菌体湿潤重量 $60 \mathrm{~g}$ より, $35.6 \mathrm{mg}$ の黄褐色粉末を 得た。

ワクチン A,C,D の凍結乾燥試料の約 100 倍の蒸溜 水溶解液をつくり，定性反応用試料とした。定量反応 用試料は, 各ワクチンの $1 \mathrm{mg} / \mathrm{m} l$ 水溶液を用いた。

（2）方法および結果

1) 定性反応

蛋白質および糖質の定性反応を行なった。糖還元反 表 1 ワクチンAの調製法
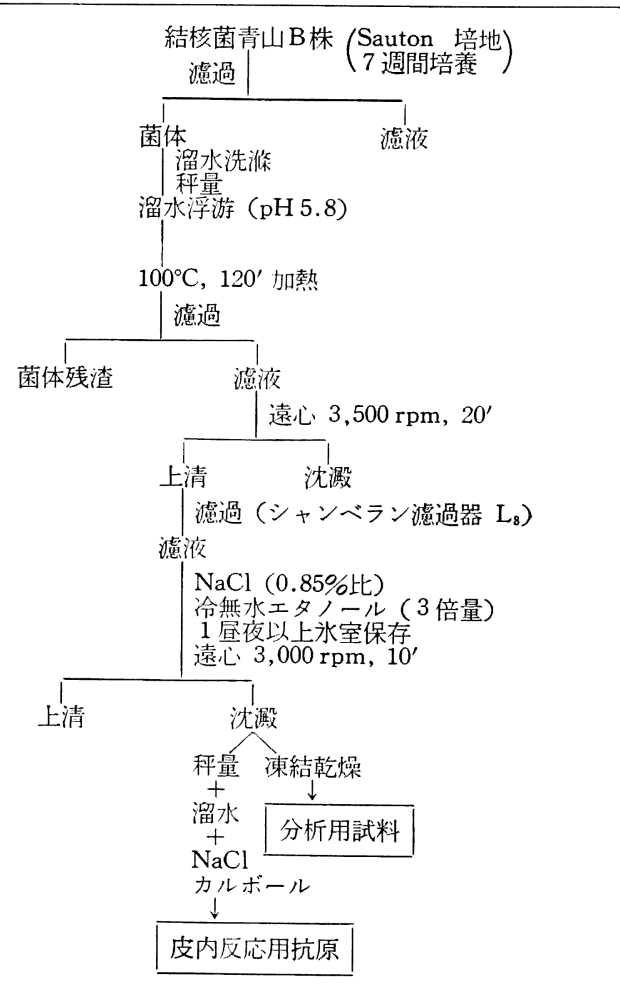

* 大学院学生 
表 2 ワリチンCの調製法

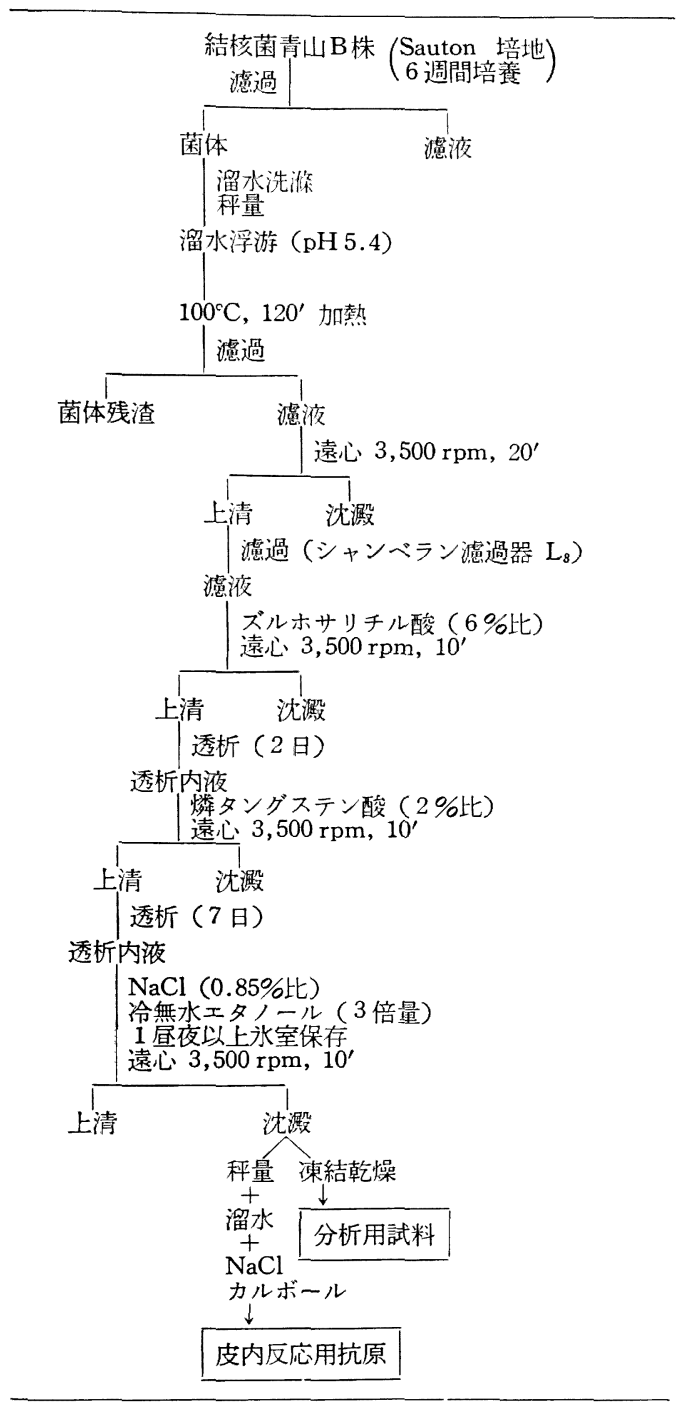

応については, 試料そのままの場合と, 酸加水分解後 の両者について行なった。酸加水分解の条件は, 終濃 度 2 規定の塩酸で $100^{\circ} \mathrm{C} ， 2$ 時間加水分解した。また 核酸構成成分中の糖 (五炭糖) が還元性を有する可能 性もあるため,イーストRNAについて，同一条件下 において酸加水分解し,糖還元反応をあわせ行なった。 その結果は，表 4 亿示すとおりである。

2）定量反応

i）核酸：核酸の含有濃度を知るために，3 種類の ワクチン $\mathrm{A}, \mathrm{C}, \mathrm{D}$ の $0.1 \mathrm{mg} / \mathrm{m} l$ 水溶液につき $260 \mathrm{~m} \mu$ 付近の紫外部吸收スペクトルを分光光度計を用いて測 定した。その結果は図 1 に示す。
表 3 ワクチンDの調製法

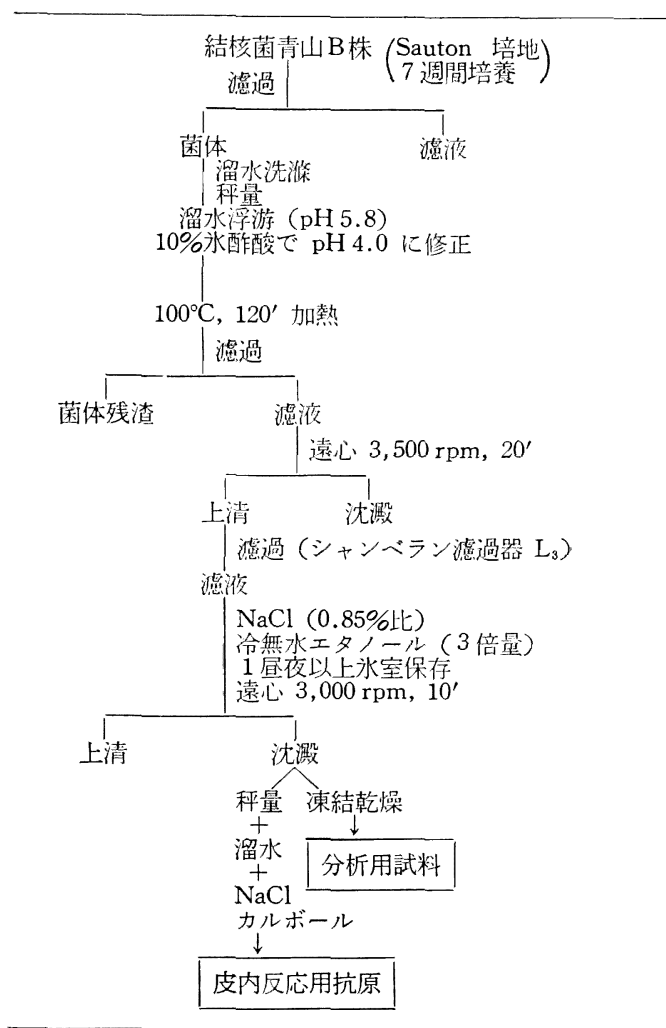

表 4 定性反応

\begin{tabular}{|c|c|c|c|c|}
\hline & & $\mathrm{A}$ & $\mathrm{C}$ & $\mathrm{D}$ \\
\hline & Molisch & H & 世 & m \\
\hline & Nylander & - & - & - \\
\hline 糖 & Fehling & - & - & - \\
\hline 質 & Benedict & - & - & - \\
\hline & Trommer & - & - & - \\
\hline 反 & 酸加水分解 & 後 & & \\
\hline 応 & Fehling & + & + & + \\
\hline 心 & Nylander & + & + & + \\
\hline & Benedict & + & + & + \\
\hline & Biuret & \pm & - & \pm \\
\hline 蛋 & Ninhydrin & + & \pm & + \\
\hline 白 & Xanthoprotein & + & - & + \\
\hline 質 & Millon & + & - & + \\
\hline 反 & Trichloroacetic acid (10\%) & + & - & + \\
\hline 応 & Sulfosalicylic acid $(20 \%)$ & + & - & + \\
\hline & Phosphotungstic acid (6\%) & + & - & + \\
\hline 核酸 & Diphenylamine & + & + & + \\
\hline 反応 & Orcinol & + & + & + \\
\hline
\end{tabular}

また，核酸の定量は，DNA では Diphenylamine

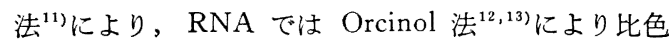




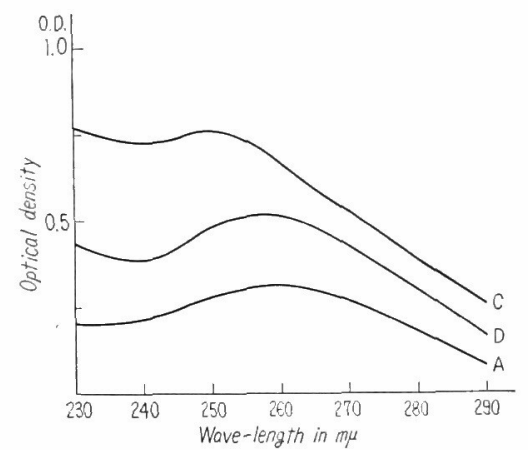

図 $1260 \mathrm{~m} \mu$ 付近の紫外部四収スペクトル 各試料 $0.1 \mathrm{mg} / \mathrm{m} l$ 水溶液の紫外部吸収スペクトル

表 5 各試料中の DNA, RNA, Polysaccharide, Protein 含有量 $(\mu \mathrm{g} / \mathrm{m} l)$

\begin{tabular}{l|r|r|r}
\hline 成 & \multicolumn{1}{|c|}{ A } & \multicolumn{1}{c|}{ C } & \multicolumn{1}{c}{ D } \\
\hline DNA & 200 & 75 & 185 \\
RNA & 306 & 298 & 290 \\
Polysaccharide & 160 & 320 & 244 \\
(glycogen unit) & 680 & 84 & 240 \\
Protein & 1.76 & 1.65 & 1.66 \\
\hline $260 \mathrm{~m} \mu$ O.D. $/ 280 \mathrm{~m} \mu$ O.D. &
\end{tabular}

注: DNA は Diphenylamine 法 (吸収極大 $595 \mathrm{~m} \mu$ ), RNA は Orcinol 法 (吸収極大 $665 \mathrm{~m} \mu$ ), Polysaccharide は Cu-Folin 法 (吸収極大 $750 \mathrm{~m} \mu$ ), でそれぞれ測定 した。

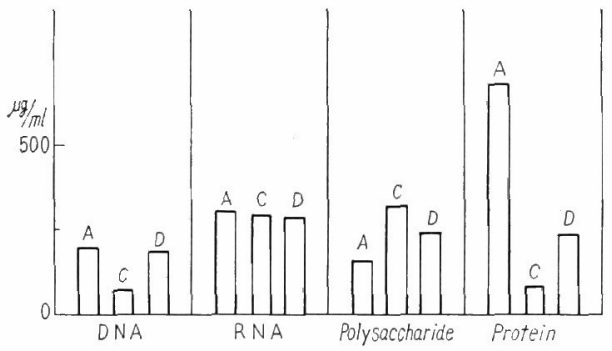

図 2 各試料中の DNA, RNA, Polysaccharide, Protein 含有量

表 6 各試料の DNA 量を 1 としたときの各成分比

\begin{tabular}{l|c|c|c}
\hline 成 & A & C & D \\
\hline DNA & 1 & 1 & 1 \\
RNA & 1.53 & 3.97 & 1.57 \\
Polysaccharide & 0.80 & 4.27 & 1.32 \\
Protein & 3.40 & 1.12 & 1.30 \\
\hline
\end{tabular}

定量した。標準曲線の作製には, 純粋なにしん精子 DNA，イースト RNA を使用した。なお，DNA む Orcinol 法により発色するため，RNA 值はこの干渉 量を補正した值である。

ii）蛋白質：Cu-Folin 法 ${ }^{14)}$ により比色定量した。
標準曲線の作製にはウシ血清アルブミンを用いた。

iii）多糖体：Anthrone 法 $^{15}$ により比色定量した。 本法による陽性物質濃度は，グリコーゲン量に換算し て表示した。なお，Anthrone とRNA および DNA との干渉が知られているが，今回定量測定に使用した 試料における核酸含有量では補正の必要を認めなかっ た。

以上 DNA, RNA, 蛋白質, 多糖体の各定量值は, 表 5 に示されている。表 5 を図示すると，図 2 のよう である。DNA 量を1として各成分の割合を比較する と, 表 6 のよらになる。

3) 沈降係数の測定

試料中の核酸, 蛋白質, 多糖体がどのような状態で 含まれ，またその分子サイズはどの位かを知るため に, 超遠心沈澱法によりワクチン $\mathrm{A}$ の沈降係数を測定 した。

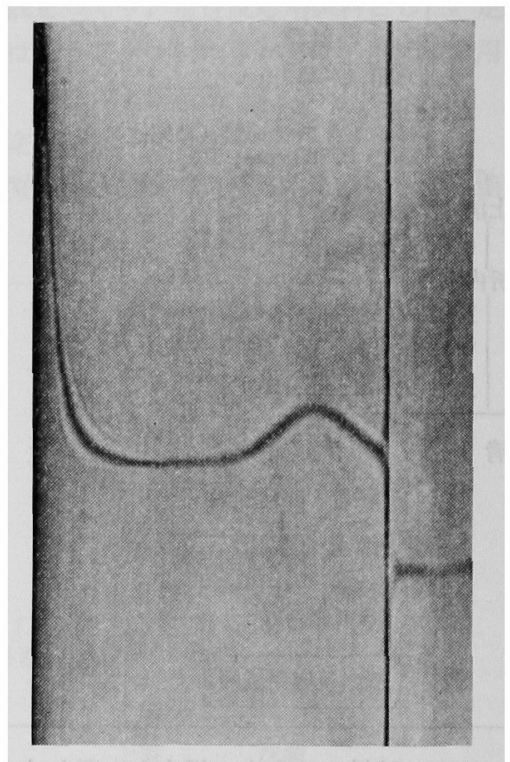

写真 1 結核ワクチンAの沈降像

$0.05 \%$ 試料を 60,000 回転で 160 分回転した。 写真は 120 分後の沈降像である。

$0.05 \%$ 試料 (0.01 M 塩化マグネシウム, $0.06 \mathrm{M}$ 塩 化カリウム定含有する $\mathrm{pH} 7.5$ の Tris 塩酸緩衡液で 稀釈）で，60,000 回転で 160 分間回転した。

写真 1 にみられよらに，底辺にわずかな乱れがあ

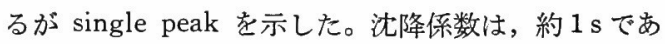
った。

(3) 小括考案

定性反応については, 従来教室から発表されたもの と同様の結果であった。ただし，糖還元反応からわか 
るように, 糖成分として還元糖を含むことが明らかに された。核酸構成成分中の糖が，還元性を有する可能 性もあるため, イーストRNAについても同じ条件で 酸加水分解を行ない，糖還元反応を試みたが陰性であ った。この結果より核酸とは別に還元性糖の存在する ことが明らかとなり, Anthrone と反応するものはこ の物質と考えられる。また DNA およびRNAの五炭 糖と Anthrone の干涉が知られており, Anthrone 陽 性物質の存在について疑問があったが, 実験試料中の DNA および RNA 量では, その干渉は考虑する必 要がなく, Anthrone 陽性物質は六炭糖以上の多糖体 と推察される。

丸山ら ${ }^{2)}$ の報告によると, ワクチン $\mathrm{A}, \mathrm{C}, \mathrm{D}$ の多糖 体と蛋白質の量的関係は以下のようである。すなわ ち, 多糖体は $\mathrm{C}>\mathrm{D}>\mathrm{A}$ の順に多く含まれ, 蛋白質 は $\mathrm{A}>\mathrm{D}$ の順に多く，Cには蛋白質は含まれていな いとしている。これは定性反応より推察された結果で あるが，今回著者は定量的にほぼ同様の結果を証明す ることができた。

表 5, 図 2 に示されるとおり，DNA については， $\mathrm{A}>\mathrm{D}>\mathrm{C}$ の順に多く含まれ, RNA は $\mathrm{A} \geq \mathrm{C} \geq \mathrm{D}$ ( 3 者はほほ等しい), 多糖体は $\mathrm{C}>\mathrm{D}>\mathrm{A}$, 蛋白質は $\mathrm{A}>\mathrm{D}>\mathrm{C}$ の順である。つまり多糖体は $\mathrm{C}$ に多く, 蛋 白質は $\mathrm{A}$ に多く, $\mathrm{D}$ は多糖体, 蛋白質ともに $\mathrm{C} と \mathrm{~A} の$ 中間の含有量を示している。

ワクチン $\mathrm{A}, \mathrm{C}$ およ゙ $\mathrm{D}$ の個々について，その成分 の割合を DNA 量を1として比較してみると表6の ようになる。ワクチンAについては, 蛋白質量が多 く, DNA 量の約 3 倍存在する。DNA と RNA 量は ほぼ等しい。多糖体量は DNA 量より少ない。ワク チンCについては多糖体量が多く, DNA 量の約 4 倍 存在し, それについで RNA 量も DNA 量の約 4 倍 存在する。蛋白質量は少なく, DNA 量とほぼ等し い。ワクチンDについては DNA, RNA, 多糖体, 蛋 白質がほほ等しい割合で存在する。

核酸の存在を証明するために $260 \mathrm{~m} \mu$ 付近の紫外部 吸収スペクトルを測定したところ $260 \mathrm{~m} \mu$ と $280 \mathrm{~m} / \mu$ の吸光度の比率は, ワクチン A, C, D の順に 1.76 , $1.65,1.66$ で, 核酸のそれと一致し, 核酸の存在は明 らかである。とくにワクチンCの吸収曲線が， A, D の曲線に比較してやや短波長寄りで，その吸収極大は $250 \mathrm{~m} \mu$ 付近であった。ワクチンCの試料の透析を数 回行ない燐タングステン酸を除去し, 吸収スペクトル を測定したところ，曲線の形はしだいに A, D に近づ
き，その吸収極大も長波長需りとなった。したがって これは燐タングステン酸の影響によるものと推察し た。また燐タングステン酸は, Anthrone 法を行なら さいにその存在により混濁を生じ, 分光光度計で測定 不可能となるため, 定量可能な段階まで, 燐タングス テン酸を十分に透析除去してから反応に供した。

超遠心沈澱法により測定したワクチンAの沈降係数 は, 約 $1 \mathrm{~s}$ であった。また, その沈降像は, 底辺にわ ずかな乱れがあるが, single peak を示し, ワクチン に含有される物質の分子サイズはあまり大きくなく, 均一な状態で存在すると考えられる。

以上より, 結核ワクチンの成分は, 多糖体, 核酸 (D NA, RNA), 蛋白質であり, ワクチンCには多糖体が 多く, ワクチンAには蛋白質が多く含有されていた。 ワクチンDは多糖体, 蛋白質ともに, ワクチン $\mathrm{A}$ とワ クチンCの中間の含有量を示した。核酸については, ワクチンCの DNA 量が, 他の 2 者に比較して少量 である以外は，とくに量的差異はなく，RNA 量は， 3 者はほぼ等しい含有量を示した。

\section{2. 精製ツベルクリン (PPDs) と結核ワクチンの 皮内反応}

\section{(1) 実験材料}

精製ツベルクリン (PPDs) は, 日本 BCG 製造会 社の一般診断用精製ツベルクリンを使用した。精製ツ ベルクリンは結核菌の培養滤液から, ツベルクリン活 性物質を分離精製し，これを凍結乾燥したもので，使 用にさいし生理食塩水に溶解する。その含有量は, 0.5 $\mu \mathrm{g} / \mathrm{m} l$ である。従来の旧ツベルクリンに比較して反応 の色調が明膫で, 硬結も触知しやすく, 非特異反応も 少ないといわれ, 現在臨床では旧ツベルクリンにかわ って，精製ツベルクリンが一般に用いられている。

結核ワクチンの調製は, 表 1 3 に示されると抢り である。

\section{(2) 方法}

i) 被験者：昭和 44 年 3 月より 6 月までの日本医 科大学皮膚科, 外科, 泌尿器科の外来㧍よび入院患者 を対象とした。

ii）皮内反応術式：精製ツベルクリンおよび 3 種の 結核ワクチンを同一個人の皮内に $0.1 \mathrm{~m} l$ ずつ注射し た。注射部位は主として背部または腹部を選んだ。

iii) 判定方法: 注射後 24 時間, 48 時間の皮内反応の 発赤と硬結の大きさを測定した。発赤の直径 $10 \mathrm{~mm}$ 以上の場合は陽性, $5 \sim 9 \mathrm{~mm}$ の場合は疑陽性, $4 \mathrm{~mm}$ 
$-14-(438)$

以下の場合は陰性とした。なお, 陽性の場合で, 直径 $19 \mathrm{~mm}$ 以下の場合は陽性(+), 直径 $20 \mathrm{~mm}$ 以上で硬 結を有するものは中等度陽性(H), 小水疮または水疮 を形成するものは強陽性(卅)とした。

iv）皮内反応の測定 : まず結核ワクチンの力価を精 製ツベルクリンと比較する目的で, 被験者 15 例につ いて, 5,000 倍結核ワクチンA, 4,000 倍結核ワクチ ン $\mathrm{A}$ ，精製ツベルクリンの 3 者を注射した。

これにより 5,000 倍結核ワクチン $\mathrm{A}$ と精製ツベル クリンが，ほぼ等しい力価を有することがわかったの で，32 例につき 5,000 倍結核ワクチン $\mathrm{A}, 5,000$ 倍 結核ワクチン $\mathrm{C}, 5,000$ 倍結核ワクチン $\mathrm{D}$, 精製ツベル クリンの 4 者を注射し， 24 時間および 48 時間後の皮 内反応の大きさを測定した。

v) 病理組織学的観察 : 5,000倍結核ワクチンA,C,
$\mathrm{D}$ と精製ツベルクリンの 4 者の皮内反応を施行した被 験者 32 例の ちち 10 例については, 注射後 24 時間, 22 例については，注射後 48 時間のそれぞれの皮内 反応部位を試験切除し, 病理組織学的に観察した。

組織標本は, 切除後, 10\%ホルマリン固定, パラフ ィン创埋, ヘマトキシリン・エオジン染色およびアザ ン染色を行なった。

(3) 結果

1）結核ワクチンの力価の決定

被験者 15 例につき, 精製ツベルクリンと 5,000 倍 および 4,000 倍結核ワクチンAの 3 者を注射した。15 例中 10 例が, 5,000 倍結核ワクチン $\mathrm{A}$ と精製ツベルク リンとがほぼ同程度の反応を示し, 残る 5 例が, 4,000 倍ワクチン $\mathrm{A}$ と同程度であった。15 例中陽性者 12 例 で，陽性者のみにつき両者を比較してみると，5,000

表 7 結核ワクチンの力価の決定

(単位 $\mathrm{mm}$ )

\begin{tabular}{|c|c|c|c|c|c|c|c|c|c|c|c|}
\hline No. & 氏名 & 性 & 年令 & 疾 患 名 & 注射 & \multicolumn{2}{|c|}{$\begin{array}{l}\text { 精製ツペルクリン } \\
24 \mathrm{hr} \quad 48 \mathrm{hr}\end{array}$} & \multicolumn{2}{|c|}{$\begin{array}{c}5000 \times \text { 結核ワクチン } \\
24 \mathrm{hr} \\
48 \mathrm{hr}\end{array}$} & \multicolumn{2}{|c|}{$\begin{array}{c}4000 \times \text { 結核ワクチンA } \\
24 \mathrm{hr} \quad 48 \mathrm{hr}\end{array}$} \\
\hline 1 & & $\hat{\delta}$ & 58 & ボーエン氏病 & 背部 & $\frac{0}{11 \times 10}$ & $\frac{12 \times 10}{12 \times 10}$ & $\frac{0}{12 \times 13}$ & $\frac{15 \times 14}{15 \times 14}$ & $\frac{13 \times 14}{13 \times 14(24 \times 20)}$ & $\frac{14 \times 11}{14 \times 11(23 \times 18)}$ \\
\hline 2 & & 우 & 32 & 急性皮虚炎 & $n$ & $\frac{16 \times 20}{16 \times 20(32 \times 35)}$ & $\frac{18 \times 17}{18 \times 17(23 \times 32)}$ & $\frac{11 \times 11}{11 \times 11}$ & $\frac{13 \times 12}{13 \times 12}$ & $\frac{14 \times 15}{14 \times 15(22 \times 24)}$ & $\frac{17 \times 19}{17 \times 19(29 \times 33)}$ \\
\hline 3 & & 우 & 28 & 慢 性 湿 疹 & $"$ & $\frac{12 \times 12}{12 \times 12}$ & $\left|\frac{10 \times 12}{10 \times 12(13 \times 17)}\right|$ & $\frac{15 \times 14}{15 \times 14}$ & $\frac{16 \times 13}{16 \times 13(21 \times 22)}$ & $\frac{17 \times 17}{17 \times 17}$ & $\frac{17 \times 15}{17 \times 15(28 \times 28)}$ \\
\hline 4 & & 우 & 34 & 急性皮膚炎 & $n$ & $\frac{0}{11 \times 11}$ & $\left|\frac{10 \times 11}{10 \times 11(18 \times 20)}\right|$ & $\frac{12 \times 13}{12 \times 13}$ & $\frac{13 \times 15}{13 \times 15(24 \times 23)}$ & $\frac{13 \times 14}{13 \times 14}$ & $\frac{10 \times 13}{10 \times 13(17 \times 20)}$ \\
\hline 5 & & $\widehat{\delta}$ & 15 & 痤㽽椂皮疹 & " & $\frac{0}{5 \times 5}$ & $\frac{0}{6 \times 5}$ & $\frac{0}{5 \times 4}$ & $\frac{0}{5 \times 5}$ & $\frac{0}{6 \times 6}$ & $\frac{0}{7 \times 6}$ \\
\hline 6 & & q & 19 & 急性皮虞炎 & " & $\frac{0}{7 \times 8}$ & $\frac{0}{9 \times 9}$ & $\frac{0}{5 \times 4}$ & $\frac{0}{6 \times 7}$ & $\frac{0}{9 \times 8}$ & $\frac{0}{10 \times 10}$ \\
\hline 7 & & 우 & 22 & 急性皮澞炎 & $n$ & $\frac{0}{10 \times 11}$ & $\frac{9 \times 9}{9 \times 9(15 \times 15)}$ & $\frac{0}{8 \times 10}$ & $\frac{0}{9 \times 11}$ & $\frac{15 \times 15}{15 \times 15(22 \times 25)}$ & $\frac{15 \times 18}{15 \times 18(25 \times 31)}$ \\
\hline 8 & & 우 & 63 & 疹 & " & $\frac{0}{7 \times 10}$ & $\frac{0}{10 \times 11}$ & $\frac{0}{6 \times 5}$ & $\frac{0}{5 \times 4}$ & $\frac{0}{6 \times 5}$ & $\frac{0}{10 \times 10}$ \\
\hline 9 & & 우 & 49 & 接触皮虞炎 & " & $12 \times 13$ & $10 \times 10$ & $11 \times 12$ & $14 \times 13$ & $14 \times 15$ & $20 \times 15$ \\
\hline 10 & & 우 & 66 & 脂 漏 性 湿 疹 & " & $\frac{0}{\frac{0}{2 \times 2}}$ & $\frac{0}{3 \times 2}$ & $\frac{0}{3 \times 2}$ & $\mid 14 \times 13(30 \times 24)$ & $\frac{0}{4 \times 5}$ & $\frac{0}{20 \times 15(32 \times} \frac{0}{5 \times 4}$ \\
\hline 11 & & 우 & 25 & 急性皮屌炎 & " & $\frac{0}{7 \times 10}$ & $\frac{10 \times 13}{10 \times 13}$ & $\frac{0}{9 \times 10}$ & $\frac{10 \times 15}{10 \times 15}$ & $\frac{0}{14 \times 12}$ & $\frac{13 \times 15}{13 \times 15}$ \\
\hline 12 & & 우 & 17 & 火傷 痏 痕 & " & $\frac{0}{10 \times 13}$ & $\frac{0}{14 \times 13}$ & $\frac{0}{14 \times 14}$ & $\frac{ \pm}{14 \times 15}$ & $\frac{ \pm}{15 \times 20}$ & $\frac{15 \times 15}{15 \times 15(22 \times 22)}$ \\
\hline 13 & & 우 & 26 & 薬 & $"$ & $\frac{14 \times 14}{14 \times 14(25 \times 26)}$ & $\frac{15 \times 15}{15 \times 15(25 \times 27)}$ & $\frac{12 \times 15}{12 \times 15(19 \times 20)}$ & $\frac{20 \times 19}{20 \times 19}$ & $\frac{13 \times 17}{13 \times 17(14 \times 22)}$ & $\frac{20 \times 23}{20 \times 23}$ \\
\hline 14 & & $\hat{\delta}$ & 20 & 疹 & " & $\frac{0}{8 \times 7}$ & $\frac{0}{7 \times 6}$ & $\frac{0}{9 \times 10}$ & $\frac{ \pm}{10 \times 13}$ & $\frac{ \pm}{13 \times 12}$ & $\frac{14 \times 12}{14 \times 12}$ \\
\hline 15 & & $\hat{\delta}$ & 24 & 脂 腺 母 斑 & $"$ & $\frac{8 \times 6}{8 \times 6(11 \times 15)}$ & $\frac{12 \times 12}{12 \times 12(19 \times 20)}$ & $\frac{0}{12 \times 12}$ & $\frac{0}{15 \times 10}$ & $\frac{11 \times 14}{11 \times 14(17 \times 26)}$ & $\frac{15 \times 19}{15 \times 19(24 \times 31)}$ \\
\hline
\end{tabular}

注：分母は発赤，（）内は 2 重発赤, 分子は硬結をあらわす。 
表 8 皮内反応の結果

\begin{tabular}{|c|c|c|c|c|c|c|c|c|c|c|c|c|}
\hline No & 氏 名 & 性 & 年令 & 疾 患 名 & $\begin{array}{c}\text { 精製ッへ } \\
24 \mathrm{hr} \\
\end{array}$ & $\begin{array}{l}\text { ルクリン } \\
48 \mathrm{hr}\end{array}$ & $\begin{array}{r}5,000 \times \text { 絈 } \\
24 \mathrm{hr} \\
\end{array}$ & $\begin{array}{c}\text { クチン A } \\
48 \mathrm{hr}\end{array}$ & $\begin{array}{c}5,000 \\
ク チ ン \\
24 \mathrm{hr} \\
\end{array}$ & $\begin{array}{l}\text { 結核口 } \\
48 \mathrm{hr}\end{array}$ & $\begin{array}{l}5,000 \\
y \text { チं } \\
24 \mathrm{hr} \\
\end{array}$ & $\begin{array}{l}\text { 結核 } \\
48 \mathrm{hr} \\
\end{array}$ \\
\hline 1 & & $\delta$ & 44 & 頊 腺 結 核 & $\frac{32 \times 20 \text { (水窇) }}{32 \times 20(43 \times 38)}$ & & $\frac{35 \times 32}{35 \times 32}$ & & $\frac{0}{5 \times 6}$ & & $\frac{0}{4 \times 3}$ & \\
\hline 2 & & $\delta$ & 28 & 黒色表皮腫 & $\frac{0}{11 \times 10}$ & & $\frac{0}{10 \times 9}$ & & 0 & & $\frac{0}{5 \times 4}$ & \\
\hline 3 & & $\delta$ & 21 & 疮 & $\frac{0}{5 \times 4}$ & & $\frac{0}{7 \times 7}$ & & $\frac{0}{4 \times 3}$ & & $\frac{0}{5 \times 5}$ & \\
\hline 4 & & ${ }^{8}$ & 45 & 曼常性狼㾉 & $\frac{33 \times 23}{33 \times 23}$ & & $\frac{ \pm}{12 \times 12}$ & & $\frac{ \pm}{11 \times 10}$ & & $\frac{0}{5 \times 6}$ & \\
\hline 5 & & $\delta$ & 41 & 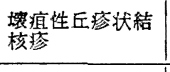 & $\frac{0}{18 \times 24}$ & & $\frac{0}{15 \times 16}$ & & $\frac{0}{5 \times 4}$ & & $\frac{0}{5 \times 5}$ & \\
\hline 6 & & $\delta$ & 42 & 黒色分芽菌症 & $\frac{ \pm}{12 \times 13}$ & & $\frac{ \pm}{8 \times 9}$ & & $\frac{0}{5 \times 3}$ & & $\frac{0}{3 \times 4}$ & \\
\hline 7 & & $\delta$ & 15 & 十二指腸沮甥 & $\frac{ \pm}{8 \times 9}$ & & $\frac{0}{5 \times 5}$ & & $\frac{0}{3 \times 3}$ & & $\frac{0}{3 \times 3}$ & \\
\hline 8 & & ${ }^{8}$ & 68 & 胆 道 蛮 & $\frac{0}{4 \times 3}$ & & $\frac{0}{3 \times 2}$ & & $\frac{0}{3 \times 4}$ & & $\frac{0}{3 \times 3}$ & \\
\hline 9 & & 8 & 52 & 腎堙琵 & $\frac{15 \times 17}{15 \times 17(20 \times 17)}$ & & $\frac{11 \times 11}{11 \times 11}$ & & $\frac{0}{2 \times 2}$ & & 0 & \\
\hline 10 & & $\delta$ & 37 & 胃随 瘦 & $\frac{10 \times 13}{10 \times 13}$ & & $\frac{0}{5 \times 7}$ & & $\frac{0}{3 \times 3}$ & & $\frac{0}{3 \times 3}$ & \\
\hline 11 & & $\delta$ & 24 & 脂 腺 母 班 & $-\frac{8 \times 6}{8 \times 6(11 \times 15)}$ & $\frac{12 \times 12}{12 \times 12(19 \times 20)}$ & $\frac{0}{12 \times 12}$ & $\frac{0}{15 \times 10}$ & $\frac{0}{5 \times 5}$ & $\frac{0}{5 \times 6}$ & $\frac{0}{6 \times 6}$ & $\frac{0}{6 \times 6}$ \\
\hline 12 & & 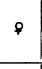 & 75 & 乳 峦 & $\frac{0}{4 \times 5}$ & $\frac{0}{5 \times 4}$ & 0 & 0 & 0 & 0 & $\frac{0}{5 \times 5}$ & $\frac{0}{3 \times 2}$ \\
\hline 13 & & $\delta$ & 27 & 弯箖 疮 & $\frac{ \pm}{15 \times 18}$ & $\frac{14 \times 15}{20 \times 22}$ & $\frac{ \pm}{15 \times 15}$ & $\frac{12 \times 11}{20 \times 20}$ & $\frac{0}{5 \times 5}$ & $\frac{0}{7 \times 7}$ & $\frac{0}{4 \times 4}$ & $\frac{0}{5 \times 3}$ \\
\hline 14 & & $\delta$ & 29 & 上皮性事跬 & $\frac{0}{9 \times 8}$ & $\frac{14 \times 13}{14 \times 13}$ & $\frac{0}{12 \times 10}$ & $\frac{14 \times 10}{14 \times 10}$ & $\frac{0}{5 \times 4}$ & $\frac{0}{7 \times 5}$ & $\frac{0}{3 \times 2}$ & 0 \\
\hline 15 & & $q$ & 52 & 胆 石 症 & $\frac{ \pm}{10 \times 14}$ & $\frac{12 \times 16}{12 \times 16}$ & $\frac{0}{7 \times 9}$ & $\frac{9 \times 12}{9 \times 12}$ & $\frac{0}{7 \times 7}$ & $\frac{0}{5 \times 6}$ & $\frac{0}{5 \times 4}$ & $\frac{0}{5 \times 5}$ \\
\hline 16 & & ${ }^{8}$ & 36 & 直 腸 癌 & $\frac{0}{10 \times 11}$ & $\frac{10 \times 11}{15 \times 21}$ & $\frac{0}{10 \times 10}$ & $\frac{9 \times 10}{15 \times 10}$ & $\frac{0}{4 \times 3}$ & $\frac{0}{4 \times 4}$ & $\frac{0}{3 \times 4}$ & $\frac{0}{3 \times 4}$ \\
\hline 17 & & $\delta$ & 60 & 胆 石 症 & $\frac{0}{5 \times 5}$ & $\frac{0}{6 \times 6}$ & $\frac{0}{5 \times 5}$ & $\frac{0}{5 \times 4}$ & $\frac{0}{4 \times 3}$ & $\frac{0}{4 \times 3}$ & $\frac{0}{3 \times 4}$ & $\frac{0}{3 \times 4}$ \\
\hline 18 & & 9 & 30 & 巨大結 腸 & $\frac{0}{5 \times 4}$ & $\frac{5 \times 5}{5 \times 5}$ & $\frac{0}{10 \times 12}$ & $\frac{10 \times 13}{10 \times 13}$ & $\frac{0}{3 \times 4}$ & $\frac{0}{4 \times 3}$ & $\frac{0}{3 \times 4}$ & 0 \\
\hline 19 & & o & 35 & 十二指晹淇懪 & $\frac{11 \times 15}{11 \times 15}$ & $\frac{10 \times 10}{12 \times 15}$ & $\frac{7 \times 9}{7 \times 9}$ & $\frac{7 \times 7}{10 \times 9}$ & $\frac{0}{5 \times 5}$ & $\frac{5 \times 5}{5 \times 5}$ & $\frac{0}{4 \times 5}$ & $\frac{0}{4 \times 3}$ \\
\hline 20 & & ${ }^{8}$ & 52 & 强迫氺失禁 & $\frac{0}{15 \times 17}$ & $\frac{12 \times 12}{25 \times 32}$ & $\frac{0}{9 \times 12}$ & $\frac{7 \times 11}{9 \times 12}$ & $\frac{0}{5 \times 3}$ & $\frac{0}{3 \times 2}$ & $\frac{0}{4 \times 3}$ & 0 \\
\hline 21 & & 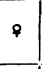 & 60 & 胆 石 症 & $\frac{17 \times 25}{17 \times 25}$ & $\frac{15 \times 25}{20 \times 32}$ & $15 \times 20$ & $\frac{12 \times 10}{14 \times 20}$ & $\frac{0}{5 \times 7}$ & $\frac{0}{8 \times 5}$ & 0 & 0 \\
\hline 22 & & $\delta$ & 27 & 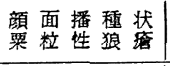 & $\frac{13 \times 15}{13 \times 15}$ & $\frac{12 \times 12}{20 \times 18}$ & $\frac{9 \times 10}{9 \times 10}$ & $\frac{12 \times 12}{12 \times 12}$ & $\frac{0}{4 \times 5}$ & $\frac{0}{5 \times 5}$ & $\frac{0}{4 \times 5}$ & $\frac{0}{5 \times 5}$ \\
\hline 23 & & 8 & 63 & 頭 部 朣 湯 & $\frac{0}{8 \times 10}$ & $\frac{7 \times 10}{15 \times 18}$ & $\frac{0}{5 \times 5}$ & $\frac{5 \times 5}{8 \times 10}$ & $\frac{0}{3 \times 2}$ & $\frac{ \pm}{5 \times 6}$ & $\frac{0}{3 \times 2}$ & $\frac{0}{3 \times 4}$ \\
\hline 24 & & ${ }^{\circ}$ & 23 & 火伤後㾍痕 & $\frac{0}{8 \times 9}$ & $\frac{0}{7 \times 10}$ & $\frac{0}{8 \times 6}$ & $\frac{0}{7 \times 9}$ & $\frac{0}{5 \times 2}$ & $\frac{0}{3 \times 2}$ & $\frac{0}{3 \times 2}$ & 0 \\
\hline 25 & & 8 & 36 & 胃ポリープ & $\frac{12 \times 15}{12 \times 15}$ & $\frac{14 \times 15}{14 \times 15(20 \times 19)}$ & $\frac{11 \times 12}{11 \times 12}$ & $\frac{15 \times 12}{15 \times 12}$ & $\frac{0}{3 \times 4}$ & $\frac{0}{4 \times 5}$ & $\frac{0}{3 \times 4}$ & $\frac{0}{4 \times 4}$ \\
\hline 26 & & $\delta$ & 30 & 胃浩瘍 & $\frac{14 \times 12}{14 \times 12}$ & $\frac{13 \times 12}{13 \times 12(21 \times 22)}$ & $7 \times 7$ & $\frac{5 \times 5}{9 \times 10}$ & $\frac{0}{4 \times 4}$ & $\frac{0}{3 \times 3}$ & $\frac{0}{4 \times 4}$ & $\frac{0}{2 \times 2}$ \\
\hline 27 & & 8 & 22 & 多形紅 玨 & $\frac{ \pm}{12 \times 12}$ & $\frac{10 \times 10}{20 \times 17}$ & $\frac{7 \times 7}{11 \times 12}$ & $\frac{12 \times 12}{17 \times 20}$ & 0 & 0 & $\frac{0}{3 \times 2}$ & $\frac{0}{3 \times 2}$ \\
\hline 28 & & $\delta$ & 61 & 胃 & $\frac{8 \times 8}{8 \times 8}$ & $\frac{8 \times 10}{8 \times 10}$ & $\frac{0}{5 \times 5}$ & $\frac{0}{3 \times 3}$ & 0 & 0 & 0 & 0 \\
\hline
\end{tabular}




\begin{tabular}{|c|c|c|c|c|c|c|c|c|c|c|c|c|c|c|}
\hline No. & 氏 & 性 & 年令 & 突 & 患 & 名 & \multicolumn{2}{|c|}{$\begin{array}{c}\text { 精製ッґ゙ルクリン } \\
24 \mathrm{hr} \quad 48 \mathrm{hr}\end{array}$} & \multicolumn{2}{|c|}{$\begin{array}{c}5,000 \times \text { 結核ワクチンA } \\
24 \mathrm{hr} \quad 48 \mathrm{hr}\end{array}$} & \multicolumn{2}{|c|}{$\begin{array}{l}5,000 \times \text { 結核ワ } \\
\eta \text { 于 }=C \quad 48 \mathrm{hr} \\
24 \mathrm{hr} \quad 48 \mathrm{hr}\end{array}$} & \multicolumn{2}{|c|}{$\begin{array}{l}5,000 \times \text { 結核口 } \\
\text { ク手之的 } \\
24 \mathrm{hr} 48 \mathrm{hr}\end{array}$} \\
\hline 29 & & 8 & 42 & 乳 & & 瘇 & & $\frac{12 \times 13}{12 \times 13(23 \times 33)}$ & & $\frac{14 \times 15}{14 \times 15(20 \times 25)}$ & $\frac{0}{3 \times 2}$ & $\frac{0}{3 \times 2}$ & 0 & 0 \\
\hline 30 & & $f$ & 22 & $\begin{array}{l}\text { 壞㾴 } \\
\text { 核疮 }\end{array}$ & 生丘疮 & & $\frac{18 \times 21 \text { (水拖) }}{18 \times 21}$ & $\frac{15 \times 15 \text { (水炮) }}{15 \times 15(21 \times 22)}$ & & $\frac{11 \times 11 \text { (水疮 })}{11 \times 11(16 \times 19)}$ & $\frac{0}{5 \times 4}$ & $\frac{0}{5 \times 3}$ & $\frac{0}{5 \times 4}$ & $\frac{0}{4 \times 3}$ \\
\hline 31 & & 9 & 65 & 胆 & 石 & 症 & $\frac{0}{8 \times 10}$ & $\frac{0}{7 \times 9}$ & $\frac{0}{5 \times 7}$ & $\frac{0}{6 \times 7}$ & $\frac{0}{4 \times 3}$ & $\frac{0}{5 \times 4}$ & $\frac{0}{2 \times 2}$ & 0 \\
\hline 32 & & $\hat{\partial}$ & 36 & 胃 & 油 & 㻤 & $\frac{15 \times 25}{15 \times 25}$ & $\frac{12 \times 21}{12 \times 21(18 \times 27)}$ & $\frac{11 \times 15}{11 \times 15}$ & $\frac{10 \times 10}{10 \times 10(14 \times 22)}$ & $\frac{10 \times 12}{10 \times 12}$ & $\frac{10 \times 10}{10 \times 10}$ & $\frac{0}{6 \times 7}$ & $\frac{0}{4 \times 4}$ \\
\hline
\end{tabular}

表 9 皮内反応の結果を総計したもの

\begin{tabular}{|c|c|c|c|c|c|c|c|c|c|}
\hline & \multicolumn{2}{|c|}{$\begin{array}{l}\text { 精製ツベル } \\
\text { ク リン } \\
24 \mathrm{hr} 48 \mathrm{hr}\end{array}$} & \multicolumn{2}{|c|}{$\begin{array}{l}5,000 \times \text { 結核 } \\
\text { ワクチン } \\
24 \mathrm{hr} 48 \mathrm{hr}\end{array}$} & \multicolumn{2}{|c|}{$\begin{array}{l}5,000 \times \text { 結核 } \\
\text { ワクチン } \\
24 \mathrm{hr} 48 \mathrm{hr}\end{array}$} & \multicolumn{2}{|c|}{$\begin{array}{l}5,000 \times \text { 結核 } \\
ワ ク チ ン ~ \\
24 \mathrm{hr} 48 \mathrm{hr}\end{array}$} \\
\hline \multirow{3}{*}{ 10例 } & 陽 性 & 7 & & 5 & & 1 & & 0 & \\
\hline & 疑予陽性 & 2 & & 4 & & 1 & & 3 & \\
\hline & 院 性 & 1 & & 1 & & 8 & & 7 & \\
\hline \multirow{3}{*}{ 22例 } & 陽 性 & 14 & 16 & 12 & 14 & 1 & 1 & 0 & 0 \\
\hline & 疑陽性 & 6 & 5 & 9 & 5 & 5 & 8 & 3 & 3 \\
\hline & 陰 性 & 1 & 1 & 1 & 3 & 16 & 13 & 19 & 19 \\
\hline
\end{tabular}

倍ワクチン $\mathrm{A}$ と等しい者 9 例，4,000 倍ワクチン $\mathrm{A}$ と 等しい者 3 例であった。その結果は表 7 に示されてい る。

\section{2) 皮内反応の結果}

被験者 32 例につき, 精製ツベルクリンと 5,000 倍 ワクチン A, C , D の 4 者を注射し, そのうち 10 例 は 24 時間後, 22 例は 48 時間後の皮内反応の大きさ を測定した。さきに調べたとおり 5,000 倍ワクチン $\mathrm{A}$ と精製ツベルクリンは，ほぼ等しい力価を示すことが さらに確認された。5,000 倍ワクチンCは 2 例が陽性 を示したが，残りはすべて疑陽性または陰性，5,000 倍ワクチンD全例疑陽性または陰性であった。この 結果は表 8 および表 9 に示す。

3) 病理組織学的観察

皮内反応を観察した 32 例につき，それぞれ判定 後, 反応部位を試験切除し, 病理組織学的に検討を加 えた。

組織の変化は，表皮，真皮，皮下組織について観察 した。皮内反応陽性部位で注，真皮における炎症性細 胞浸潤, 真皮血管の変化（拡張，充盈，出血など）, 真 皮上層部浮腫, 膠原線維のフィブリノイド変性がみら れた。膠原線維のフィブリノイド変性は，陰性部位で もみられた。表皮の変化は, 真皮の㷋症の強度な例に みることができた。皮下組織は，す心゙ての例について は観察できなかったが，観察できた限りにおいては， 真皮の変化と同様の所見を示した。皮内反応陰性部位 では，顕著な組織変化はみられなかった。これらの結
果は表 10 および表 11 に示されている。

つぎにその主な変化について症例をあげて解説を加 える。

症例 1 (No. 25): 36 才。男. 胃ポリープのため胃切除術 を行なった患者. 腹部にて皮内反応施行 - 注射後 48 時間で試 験切除した。

精製ツベルクリン：皮内反応，中等度陽性．病理組織所 見, 写真 2,4 に示す. 表皮は肥厚し, 細胞内浮腫, 細胞間浮 腫をみる．真皮に強度の細胞浸潤（リンパ球様細胞，好中 球, 好酸球よりなる)をみる. 細胞浸潤は汗腺, 脂腺, 血管 周囲にとくに強い，血管は拡張し充盈する．膠原線維のフィ ブリノイド变性があるー皮下組織に 細胞浸潤を認める（写真 $2,4)$.

結核ワクチンA：皮内反応, 陽性. 病理組織所見, 写真 3, 5 に示す. 表皮に細胞内浮腫および細胞間浮腫をみる. 真皮 には中等度のリンパ球，好中球，好酸球よりなる炎症性細胞 浸潤があり，主として血管および汗腺周囲に強い，毛細血管 は拡張し充盈する、膠原線維のフィブリノイド变性が認めら れる.皮下組織に細胞浸潤がある(写真 3,5).

結核ワクチン $\mathrm{C}$ : 皮内反応, 陰性. 病理組織所見, 写真 6 に示す．表皮に変化なし，真皮にごく軽度の細胞浸潤をみる. 膠原線維のフィブリノイド変性を認める（写真 6)。

結核ワクチンD：皮内反応, 陰性. 病理組織所見, 写真 $T$ に示す. 表皮に変化なく, 真皮にごく軽度の細胞浸潤をみる, 膠原線維のフィブリノイド变性がある(写真 7).

症例 2 (No. 29) : 42 才. 女. 乳癌のため乳房切断術を行な った患者. 胸部にて皮内反応施行. 注射後, 48 時間で試験切 除した。

精製ツベルクリン: 皮内反応, 中等度陽性. 病理組織所見, 写真 8,10 に示す. 表皮は肥厚し, 細胞内浮腫, 細胞間浮腫を みる。真皮には強度のリン八゚球，好中球，好酸球などからな る炎症性細胞浸潤をみる。血管は拡張, 充盈, 出血し, 真皮 上層部に浮腫がある, 膠原線維のフィプリノイド変性をみる. 皮下組織にも真皮と同樣の細胞浸潤を認める(写真 8,10).

結核ワクチンA：皮内反応，中等度陽性。病理組織所見， 写真9,11 に示す. 表皮は肥厚し, 細胞内浮腫と軽度の細胞 間浮腫をみる. 真皮には強度の炎症性細胞浸潤 (リンパ球, 好中球, 好酸球よりなる) と, 毛細血管の拡張, 充盈, 出血 などの血管变化および 真皮上層部の浮腫がある。膠原線維の フィブリノイド変性をみる。皮下組織にも真皮と同様の細胞 浸潤を認める(写真 9,11).

結核ワクチンC：皮内反応, 陰性. 病理組織所見, 写真 12 
表 10 病理組織像 (24時間後)

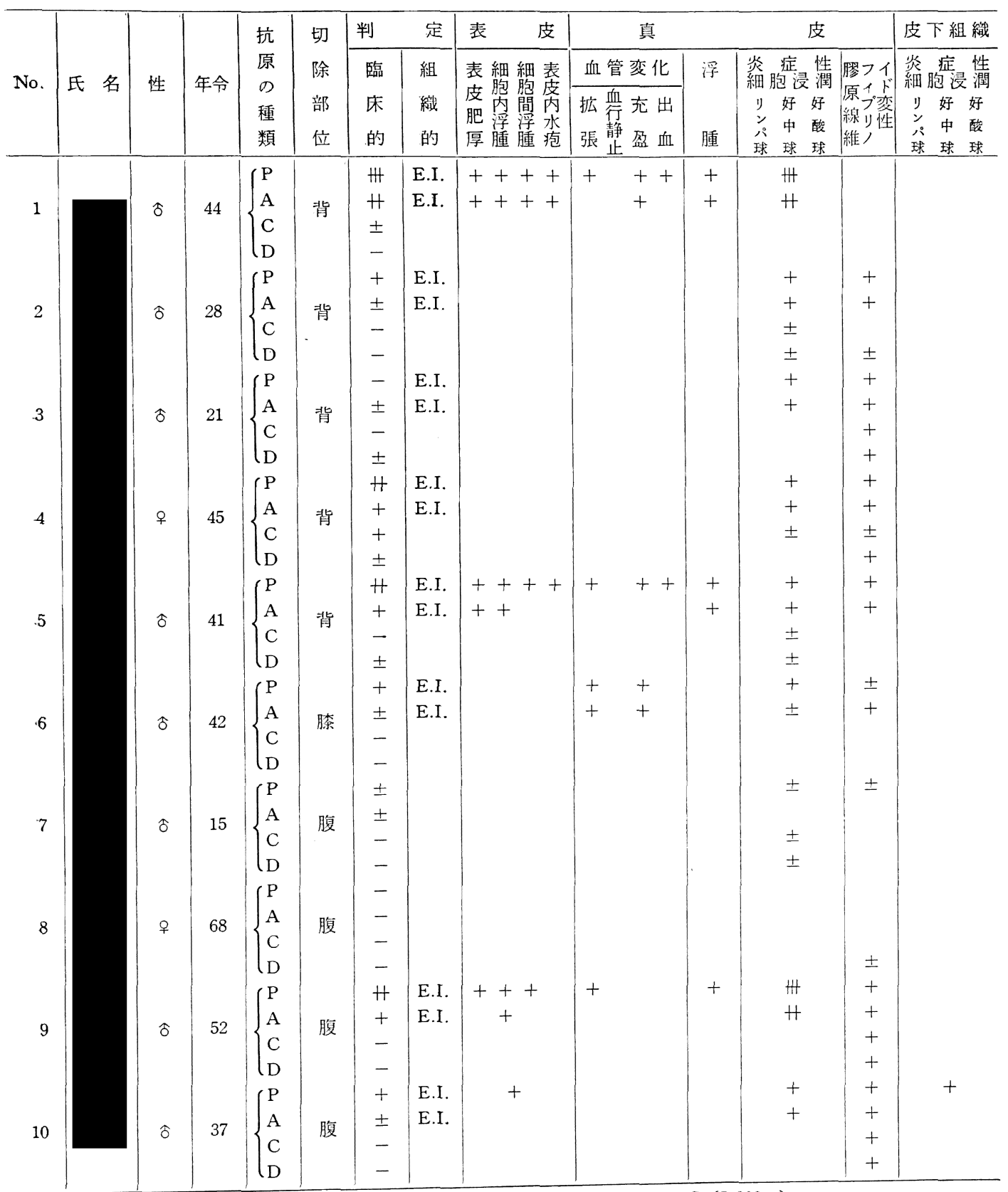

注 : P; PPDs 精製ツベルクリン, A ; 結核ワクチンA $(5,000 \times), \mathrm{C}$ ；結核ワクチンC $(5,000 \times)$,

$\mathrm{D}$; 結核ワクチンD $(5,000 \times)$, E.I.; Exudative inflammation.

に示す、膠原線維のフィプリノイド変性のほか㵔変なし

(写真 12).

結核ワクチンD：皮内反応，陰性・病理組織所見，写真 13 に示寸. 膠原線維のフィブリノイド変性のほかは, 表皮, 真 友とも化变化なし（写真 13）。
症例 3 (No. 8) : 68才. 女. 胆道癌のため腫瘍摘出術を行 なった患者, 腹部に皮内反応施行. 24 時間後に試験切除し た。

精製ツベルクリン：皮内反応, 陰性. 病理組織所見, 表 皮, 真皮, 皮下組織ともに著変なし. 
表 11 病理組織像 (48 時間後)

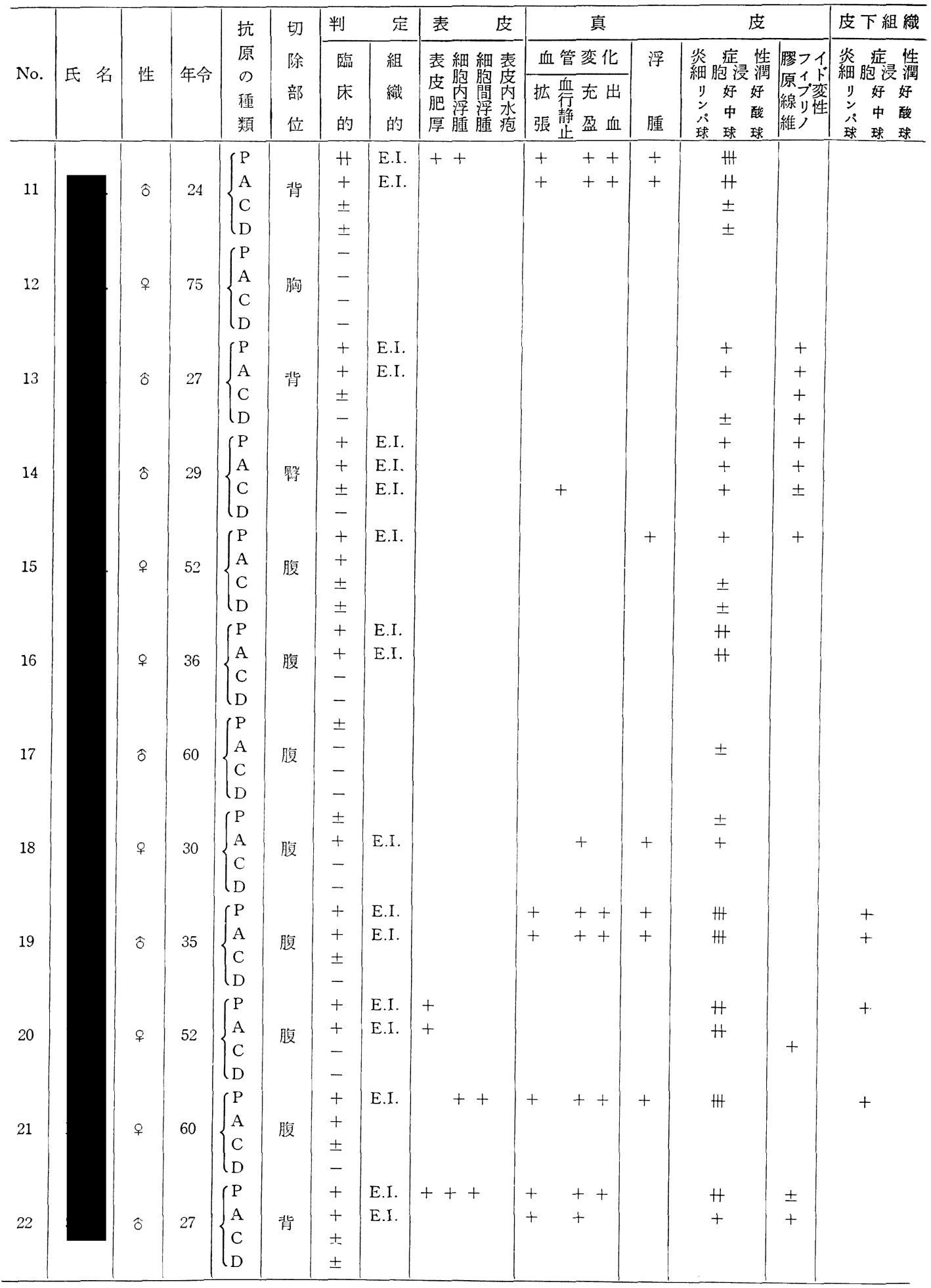


(443) $-19-$

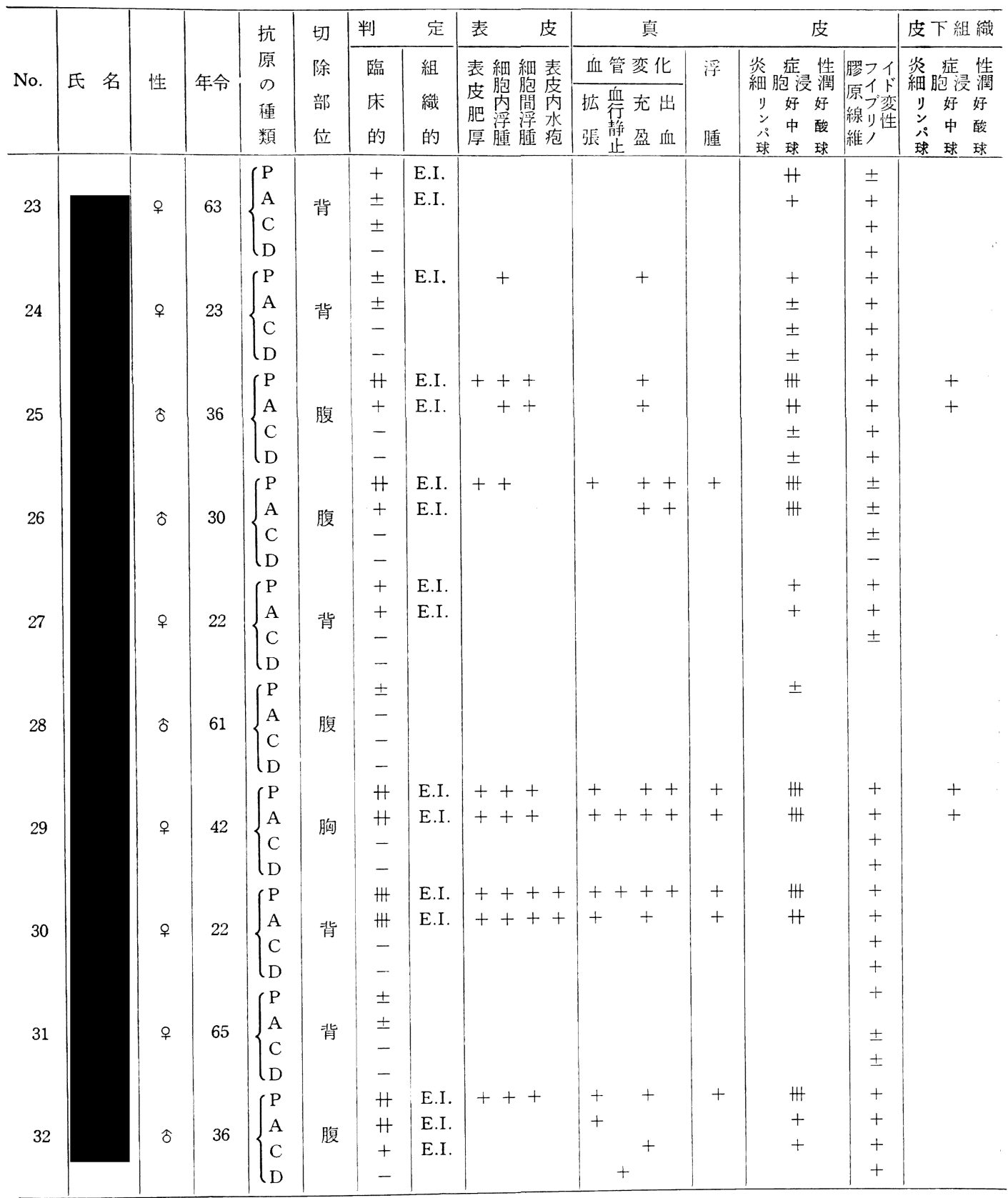

結核ワクチンA：皮内反応，㓌性。病理組織所見，著变な ᄂ.

結核ワクチンC : 皮内反応, 陰性。病理組織所見, 著变な L.

結核ワクチンD：皮内反応，除性．病理組織所見，著変な ᄂ.

(4) 小括考案

5,000 倍結核ワクチン $\mathrm{A}$ は, 精製ツベルクリンと同
程度の皮内反応用抗原となりらるが， 5,000 倍ワクチ ンCおよびワクチン $\mathrm{D}$ は，皮内反応用抗原としては使 用できないことが判明した。

病理組織学的に皮内反応部位を観察した結果，精製 ツベルクリン反応および結核ワクチン反応陽性例で は, 急性渗出性炎症像を示し, 皮虞において抗原抗体 反応が抢きたことがわかる。精製ツベルクリンと 


$$
-20-(444)
$$

5,000 倍ワクチンAは, 組織傷害性に働き, 同ワクチ ンCおよびワクチン D組織傷害性はごく轻度か, あ るいはまったくないかであった。

ツベルクリン反応と結核ワクチン反応とを比較する と, ツベルクリン反応の方が, やや反応の程度が強か ったが，質的な差異はみられなかった。また結核口ク チンの注射後 24 時間と 48 時間の反忘についても比 較したが，特別な差異は観察できなかった。

病理組織学的変化の強さは, 皮内反応の程度に平行 し, 皮内反応強陽性のものほど, 表皮の変化, 真皮の 血管変化および強度の炎症性細胞浸潤をみた。膠原線 維のフィブリノイド変性が, 炎症の強さと平行しなか ったのは，この変化が注射などの機械的刺激によりお こりらるためと考えた。

土田 ${ }^{16)}$ はモルモットを用いて，ツベルクリンによる 皮内反応の組織について検討し, 主たる変化は, 血管 反応 (充血, 毛細管扩張, 出血など), 細胞浸潤 (多 核白血球, 円形細胞浸潤, 細網内皮采細胞), 膠原線 維の膨化ないし緻密化をあげた。著者の観察とほぼ同 様の結果を示している。

松本 ${ }^{17)}$ は，ヒトのツベルクリン反応の組織像を経時 的に観察した。1 4 時閒後, 血浆および好中球の渗 出, 血管内皮細胞, 外膜細胞の変性, 基底膜の異常染 色性。8 時間後, 血管壁の透過性は高まっていなが ら, 内膜細胞の形態は旧に復し, 血管周囲組織の外膜 細胞や細絧細胞が賦活し 数を增す。12〜24 時間後, リンパ球が混じて，2 日後には，リンパ網状織の形成 が高度になるとしている。初期の組織像については観 察していないので比較できないが，24〜48 時間後の 組織像は, リンパ網状織をリンパ球様細胞浸潤と解釈 すれば，著者の観察と一致しているといえよう。

芳野 $^{18,19)}$ ，田中 ${ }^{20)}$ は，モルモットを用いて，旧ツ ベルクリン， $\mathrm{BCG}$ 死菌および結核ワクチン $\mathrm{A} の$ 皮内 反応をそれぞれ比較検討した結果, 組織学的に遅延型 アレルギー反応像（真皮における小円形細胞浸潤）を 得，3者の間に質的な差は羿めていない。

芳野 ${ }^{19)}$ は, 病理組織像で, 2,000 倍旧ツベルクリン 反応と 10,000 倍結核ワクチンA反応とがほぼ一致し た所見を示したとしている。一方，飯田 ${ }^{9}$ も，ヒトの ツベルクリン皮内反応により，10,000 倍ワクチンA の力価は，2,000 倍旧ツベルクリンに匹敵するとし た。これらの結果は著者の 5,000 倍ワクチンAと, 精 製ツベルクリンが等しい力価を有するという結果と少 しく異なる。この相違は, 旧ツベルクリンと精製ツベ
ルクリンの差異によるものと考える。つまり精製ツべ ルクリンの方が，旧ツベルクリンより，発赤, 硬結が 大きくでるということになる。

山田 ${ }^{21}$ は，ツベルクリン反応の部位的差異について 検討し，これを局所アレルギー炎症の成立機構に起因 するよりも, 生理的部位的機構に起因すると推論し た。著者の行なった皮内反応は，背部および腹部で， 場所が一定していない点について, 部位的差異は考慮 にいれる必要があるが，同一個人についての 4 者の皮 内反応の比較に重点をおいたので, 部位的差異は 2 次 的なものと思われる。

\section{総括および考案}

丸山の結核ワクチンには， $\mathrm{A}, \mathrm{B}, \mathrm{C}, \mathrm{D}$ の 4 種があ り，臨床的に使用されるのは主に A, C , D の 3 種で ある。丸山が最初に使用したのはワクチンAで, 皮膚 結核症に対する当時の臨㦿実験は好成績を示したが， 病巣刺激作用を伴う場合もありかならずしも理想的と はいえなかった。ワクチン Aを定性反応上検討する と, 主として多糖体, 蛋白質画分よりなることが判明 したので，まず蛋白質画分を分離し（ワクチンB）, 使用したところ病巣刺激がはなはだしく，到底治療に 用いることは不可能であると断定した。よってワクチ ンAより刺激因子すなわち蛋白質を除去し，有効物質 のみを抽出しようと企てた。その結果, 開発したのが ワクチンCで，ワクチンAより旧ツベルクリン活性因 子，すなわち蛋白質を除去したものである。ワクチン Cは多糖体を主成分とし, 血中抗体産生能力なく皮膚 反応原性は微弱であり, 臨床実験は非常な好成績をお さめた。さらに種々吟味し実験を重さねた結果, ポリ ペプチドの含有量が少なければ少ないほど，良好な臨

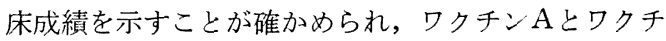
ンCの中間型ともいうべきワクチンDが調製された。

またワクチン調製のさいの溜水浮游液の $\mathrm{pH}$, 菌体 加熱時間などについても研究が加えられ, もっとも臨 床的に有効なワクチンは，ワクチンCであり，皮膚反 応原性の少ないものほど臨床的には治効作用が大であ り，皮膚反応原として優秀な物翼は治療用ワクチンと しては不適当であるといら結論に達した。

著者は以上の事実をもととして有効因子の検討を， ワクチンの成分の分析と, 各成分の皮膚反応原性の検 討から追及した。

從来本ワクチンの成分に関しては, 定性反応が主で あった。 
結核ワクチンの生化学的分析を試みたのは浦辺 ${ }^{5)} ゙$ で, 紫外部吸収スペクトルで核酸の吸収曲線を得ている。 また Sutherland の Microprotein Methode により 蛋白質の定量を, Anthrone 法により糖質の定量を試 みている。

著者は本ワクチンの分析を定性のみならず，定量的 に精しく検討した結果, 臨床上もっとも有効であるワ クチンCに多糖体がもっとも多く, ワクチンの有效性 と多糖体の含有量比が一致することを証明した。

つぎに，本ワクチンの皮膚反応原性について追及し た。

結核ワクチンの皮内反応については, 飯田 ${ }^{9)}$, 平 井 ${ }^{10}$ の報告がある。

飯田9 は, ワクチン $\mathrm{A}$, ワクチン $\mathrm{B}$ (ワクチン $\mathrm{A} の$ 蛋白質画分), ワクチン $\mathrm{C} の$ 皮膚反応原性を検討し, $\mathrm{B}>\mathrm{A}>\mathrm{C}$ の順であるとした。B抢よび $\mathrm{A}$ 溌赤を招 来する傾向が強い結果を, 臨床面の成績および文献上 の成績と考え合わせ, 発赤因子は病巣刺激因子とな り，硬結因子は治癒促進因子となると報告した。

平井 ${ }^{10)}$ は, 菌体加熱前の溜水浮游液の $\mathrm{pH}$ と抽出物 との関倸を皮内反応汇より検討し，アルカリ側抽出の 場合は発赤を主徵とし, 酸性側抽出の場合は硬結を主 徵とする所見を明らかにした。

著者はツベルクリン反応と結核ワクチンの皮内反応 を行ない，病理組織学的に検討した結果，5,000 倍結 核ワクチンAは精製ツベルクリンと同程度の皮内反応 用抗原として使用できるが， 5,000 倍結核ワクチンC およびワクチン Dは, 皮内反応用抗原としては使用で きないことが判明した。

今回著者の行なった実験では, 蛋白質の多いワクチ ンAは発赤, 硬結を示し, ツベルクリンが結核菌培養 滤液中の蛋白質であることを考えると, 蛋白質が皮膚 反応原性物質, すなわち皮内反応の活性因子と結論で きる。

なお, ワクチンAでは病理組織学的に急性渗出性炎 症像を示し組織傷害性に働き, ワクチンC㧍よびワク チン Dは, 病理組織学的な変化はごく軽度で, 組織傷 害性は認められなかった。ワクチンC, ワクチンDに ついては, 硬結も触知できず， 5,000 倍の稀釈度では 硬結因子について言及することはできなかった。しか し多糖体を多く含むワクチンCが臨床的にもっとも有 効で, 病宩刺激作用もなく, 皮膚反忘原性が少ない事 実から, 臨床的有効物質が多糖体であろうことは推論 できる。
なお，核酸衫については，ワクチン $\mathrm{A}, \mathrm{C}, \mathrm{D}$ いず れにもほぼ等しい割合に含まれている。よってワクチ ン $\mathrm{A}, \mathrm{C}, \mathrm{D}$ は丸山のいらように複合多糖体 ${ }^{23)}$ であり， その臨床効果はかかる複合多糖体を通じて把握されて いるのであるが，臨床上有効なワクチンと成分上の多 糖体の含有比は一致するのに反し，核酸のそれとは無 関係であることより，治療上の活性因子の主役を演ず るものはやはり多糖体で, 核酸は単にワクチンの構成 成分としてのみ存在するか, あるいは多糖体への補助 的作用を呈するにすぎないとみなすべきであろう。

以上，ワクチンの有効因子の検討を成分の上から， また皮膚反应原性加追及した結果有効因子の主役を 演ずるものは多糖体であるとの結論をうるにいたっ た。この事実は丸山の多年にわたる研究をさらに確実 に裏ゔけたものと信ずる。

\section{結語}

3 種の結核ワクチン A, C, D について, 生化学的 分析と皮内反応を施行し, 以下の結果を得た。

1) 結核ワクチンの成分は、核酸 (DNA, RNA), 蛋白質, 多糖体であり, 多糖体の含有量比とワクチン の有効性が一致することを確認した。

2） 5,000 倍結核ワクチン $\mathrm{A}$ は, 皮膚反応原性に打 いて精製ツベルクリン $(0.5 \mathrm{r} / \mathrm{m} l)$ とほぼ等しい力価 を有することを証明した。

5,000 倍ワクチン C $, 5,000$ 倍ワクチン Dは, 皮内反 応用抗原としては使用不可能であることがわかった。

3）精製ツベルクリン皮内反応, 結核ワクチン A皮 内反応はともに, 病理組織学的に急性渗出性炎症像を 示し, 組織傷害性に働いていることが判明した。両者 の間には質的差異は認めず, 皮内反応の強さに平行し た病理組織像を示した。

4）臨床上の治療効果はワクチンCがもっとも顕著 で病巣反応を伴らことなく, ワクチン D はこれにつ ぎ，ワクチンAは有効ではあるがしばしば病巣刺激作 用を呈することと，2)の事実を考え合せて，皮膚反応 原性の優秀な物質はかならずしも治療用には適当でな いことを明らかにした。

なお，3)の事実は組織学的にもこれを裏づけるもの である。

5）核酸については, ワクチン $A, C, D$ いずれも ほぼ等しい割合に含まれており，臨床上有効なワクチ ンと成分上の多糖体の含有比は一致するのに反し, 核 酸のそ机とは無関係であることより，治療上の活性因 
子の主役を演ずるものは多糖体で，核酸は単にワクチ ンの構成成分としてのみ存在するか，あるいは多糖体 への補助的作用を呈するにすぎないと考えた。 稿を終るに臨み、ご愁篤なご指導とご校閲を賜わった恩師
丸山千里名誉教授, 原田誠一教授に 蚛心より感謝の意を表す るとともに, 本研究にご指導, ご鞭撻をいただいた宿谷良一 教授，福土勝成教授に深く感謝する。

（本論文の要旨は昭和 44 年 9 月第 37 回日本医科大学医学会 総会において発表した。)

\section{文献}

1）丸山千里, 野村義弘, 藤濢 弘, 饭田康衛, 原田誠一, 宇田貞一郎, 武田壮太良, 宗像 醇, 近喰利光, 横田 監物 : 新ワクチン（結核菌の特異抗原性物質溶液）に よる皮䖉結核の治療について。日本医事新報, 1428， 12,1951 .

2) 丸山千里, 飯田康衛, 平井敏之, 浦辺清道, 福本寅雄, 水野綾子, 塩沢富美子, 渡辺芳子, 硲 省吾, 本田光 芳：結核ワクチン（結核菌体抽出物質）による皮䖉結 核症, BCG 潰济, 実駼結核症および瀨の治療に関す る研究. 日皮会誌, 74, 139, 1964.

3）松下正幸：結核菌補体結合反応敒関する研究。日医大 誌, 24, 122, 1957.

4）新海 恒: 結核の感作血球凝集反応阔する研究. 日 医大誌, 23, 615, 1956.

5) 浦辺清道: 結核菌より 分離抽出世る特異抗原性物質 （丸山ワクチン）に関する基礎的研究. 日医大誌，27, 1493,1960

6) 福本寅雄: 結核菌体加熱浸出液による結核感作血球凝 集反応. 日医大誌, 27, 1617, 1960.

7）文入正敏：結核菌長時間加熱浸出液の免疫学的性状に 関する研究. 日医大誌, 27, 1506, 1960.

8）本田光芳：結核の感作血球凝集反応および溶血反応に 関する研究. 日医大誌, 32, 1, 1965.

9）飯田康衛：結核菌上り 分離抽出せる特異抗原性物質溶 液による皮内反応仪関する研究. 結核, 26, 284，307， $361,1951$.

10）平井敏之：結核菌菌体より 分離抽出せる特異抗原性物 質溶液の皮内反応敒関する研究. 日皮会誌， 68, 725, 1958.

11) Seibert, F.B. : Removal of the impurities, nucleic acid and polysaccharide, from tuberculin protein. J. Biol. Chem., 133, 593, 1940.

12) Bial, M. : Ueber die Diagnose der Pentosurie mit dem von mir angegebenen Reagens. Deut. med. Wochschr., 29, 477, 1903.
13) Kerr, S.E., \& Seraidarian, K. : The separation of purine nucleosides from free purines and the determination of the purines and ribose in these fractions. J. Biol. Chem., 159, 211, 1945.

14) Lowry, O.H., Rosebrough, N.J., Farr, A.L., \& Randall, R.J. : Protein measurement with the Folin phenol reagent. J. Biol. Chem., 193, 265, 1951.

15) Morris, D.L. : Quantitative determination of carbohydrates with drywoods anthrone reagent. Scien ce, 107, 254, 1948.

16）土田輝子：ツベルクリン皮内反応の組織像について. 結核, 16, 682, 1938.

17) 松本武四郎 : 病理学講本, 呼吸器. p. 159, 杏林書院, 1963.

18）芳野 隆：結核菌体抽出物質（丸山ワクチンA）によ る皮内反応および BCG 死菌皮内反応に関する臨床診 断的研究. 日医大誌, 33, 154, 1966.

19）芳野 隆：結核菌体抽出物質（丸山ワクチンA）によ る皮内反応および BCG 死菌皮内反応に関する臨床診 断的研究. 続報, 動物実験による検討. 日医大誌, 34, $145,1967$.

20）田中 聖：抗癌剤，ステロイド，脱感作等による旧ッ ベルクリンアネルギー時における BCG 死菌コッホ現 象および新ツべルクリン（丸山ワクチンA）によるフ レルギー反応に関する研究. 日医大誌, 35, 7, 1968.

21）山田佳也：皮膚反応の研究, 第 1 編, ツベルクリン反応 の部位的差位一各部位に皮内注射した放射性同位元素 $\mathrm{P}^{82}$ 溶液の吸収傾向との関連において. 日皮会誌, 78, 1001, 1968.

22）積田 享, 野島庄七: 結核菌菌体成分の研究. 医学生 物学最近の展望, 1, 163, 1960 .

23）積田 享: 結核菌の菌体成分の化学. とくに複合糖質 についての 2,3 の知見. 蛋白質, 核酸, 酵素, 14, 43, 1969.

（受付：1969 年 10 月 8 日)

\section{付図説 明}

写真 2 No. 25 精製ツベルクリン $(20 \times)$ 表皮の軽度の浮腫ならびに真皮浅層より真皮全体に およぶ中等度の浮腫. 血管の充盈強度で一部出血を みる、ところにより膠原線維の膨化がある。リンパ 球, 好中球, わずかな好酸球よりなる炎症性細胞浸 潤が真皮より皮下脂肪織の深部にまでみられる。

写真 3 No. 25 結核ワクチンA $(20 \times)$

表皮の軽度の浮腫. 精製ツベルクリンと同様に真皮 全体の浮脃，真皮より皮下脂肪織におよぶ炎症性細 胞浸潤をみる。

写真 4 No. 25 精製ツペルクリン $(200 \times)$
炎症性細胞浸潤は，血管周囲性，汗腺周囲性，毛譬 周囲性にとくに強く認められ，一言でいえば強度の 渗出性炎症像を示す.

写真 5 No. 25 結核ワクチンA $(200 \times)$ 炎症性細胞浸潤はリン八球, 好中球, わずかな好酸 球よりなる。

写真 6 No. 25 結核ワクチンC $(20 \times)$ 表皮の浮腫まったく認められず，血管充盈は軽度で 真皮の浮腫はほとんどなく, きわめて軽度に血管周 囲性にリンパ球，好中球の浸潤を認めるにすきない。

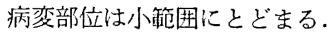



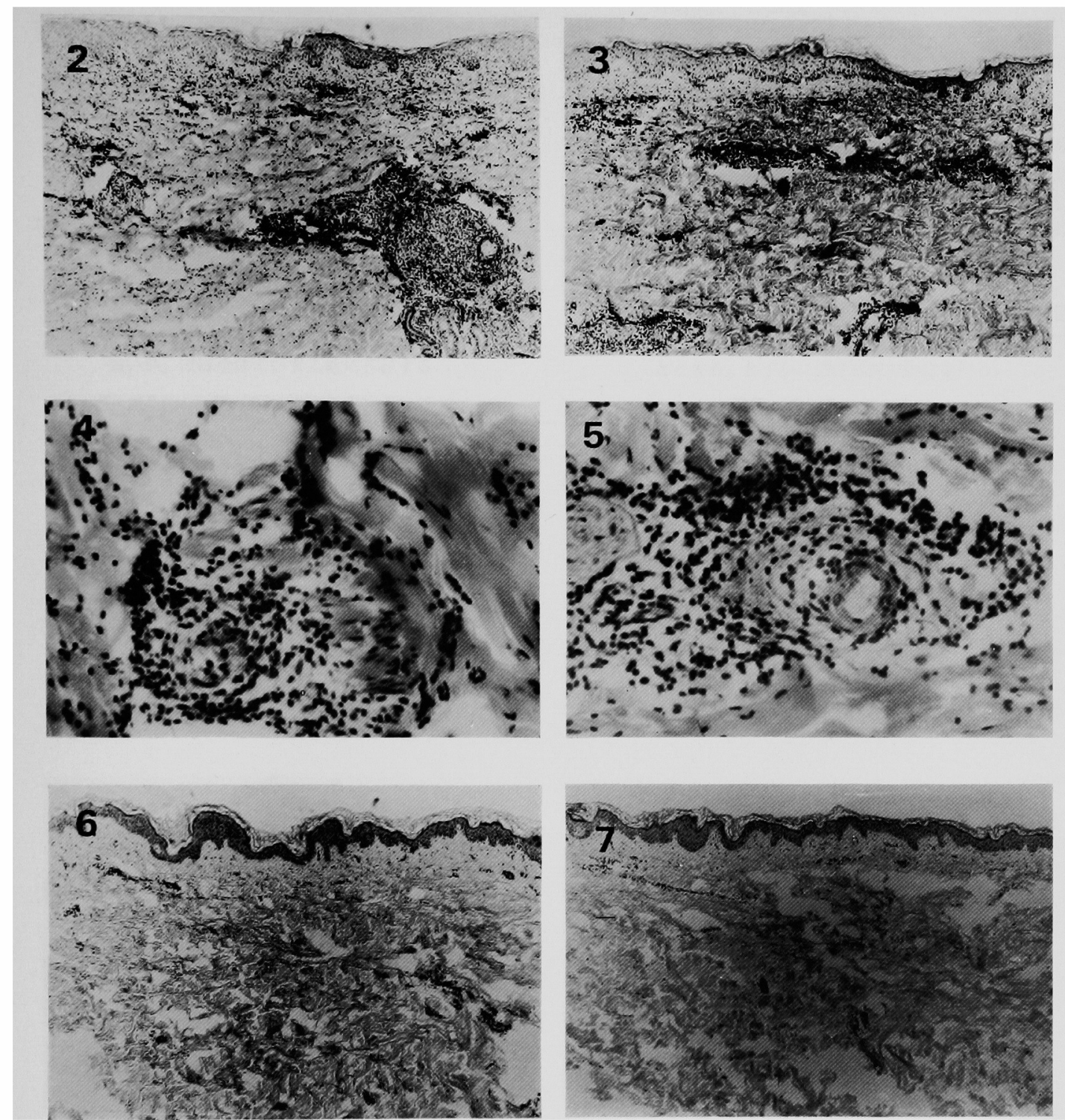

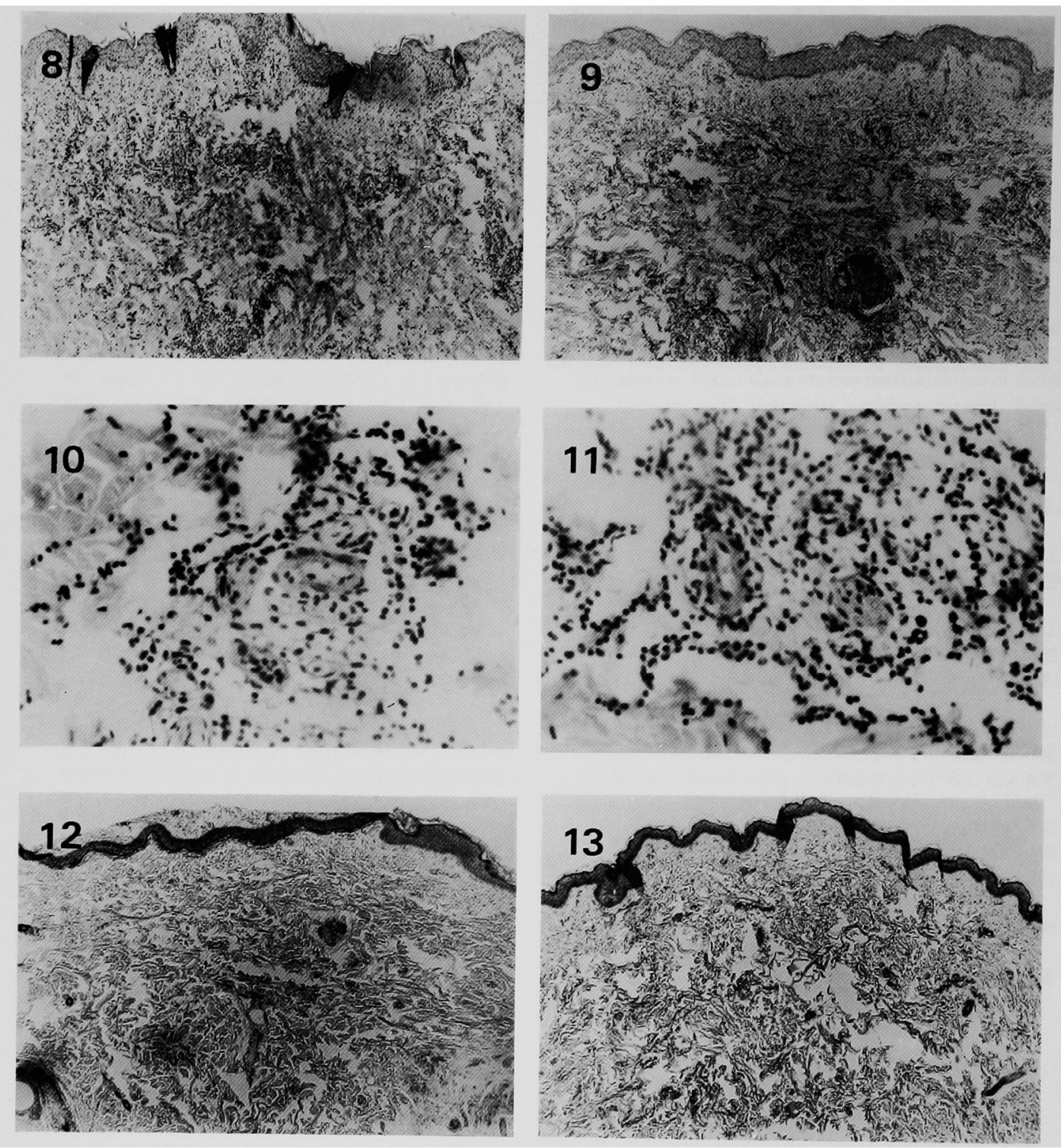
写真 7 No. 25 結核ワクチンD $(20 \times)$

表皮は正常, きわめて軽度のリンパ球, 好中球より なる血管周囲性細胞浸潤をみる。

写真 8 No. 29 精製ツベルクリン $(20 \times)$

表皮の浮腫, 真皮全体の浮腫. 真皮より皮下脂肪織 の深部にまでおよぶ炎症性細胞浸潤があり，とくに 血管周囲，汗腺周囲，毛褧周囲に強い，ところによ り膠原線維の膨化がある. 渗出性炎症が真皮より皮 下組織までびまえ性に認められ，变性炎や増殖性炎 症像はほとえどない,

写真 9 No. 29 結核ワクチンA $(20 \times)$ 表皮の軽度の浮腫と真皮全体の中等度の浮腫. 真皮 全体より皮下脂肪織の深部にまでおよぶ強度の炎症 性細胞浸潤があり, 精製シベルクリンとほとえど差 がない. 細胞浸潤は血管, 毛㖶, 汗腺周囲にとくに 強いが，ほほ全体にびまえ性に存在する。
写真10 No. 29 精製ツベルクリン $(200 \times)$ 血管を中心とした強い浮腫と, リンパ球, 好中球, 好酸球よりなる細胞浸潤を認める.

写真11 No. 29 結核ワクチンA $(200 \times)$ 血管, 神経を中心とした強い浮腫とリンハ球, 好中 球，好酸球よりなる細胞浸潤を認める.

写真12 No. 29 結核ワクチンC $(20 \times)$ 表皮は正常, 真皮浮腫ほとえどなく, きわめて軽度 の血管周囲性細胞浸潤を認める。なお，血管内皮細 胞の腫大, 外膜細胞の軽度の增生による壁の 2 層性 形成がみられる. 汗腺, 毛洨, 皮下脂肪織に著変は ない.

写真13 No. 29 結核ワクチンD $(20 \times)$

表皮は正常. 真皮浮腫きわめて軽度にして血管周囲 性細胞浸潤も軽度にみられるが病変部位は小範囲に とどまる・わずかに膠原線維の膨化をみる。 